УДК 57.083.3-034.4

(C) 2014

Серветник Н. Р., аспірант

(Науковий керівник - доктор біологічних наук, професор, академік НААНУ В. В. Снітинський)

Львівський національний аграрний університет

\title{
ВПЛИВ ІОНІВ СВИНЦЮ НА ІМУНОБІОЛОГІЧНІ ПОКАЗНИКИ У КУРЕЙ-НЕСУЧОК
}

\section{Рецензент - доктор біологічних наук С. О. Вовк}

\begin{abstract}
Представлено результати досліджень впливу згодовування різних доз ацетату свинию на імунобіологічні показники курей-несучок. Встановлено, щчо за надходження в організм курей іонів свиниюю в кількостях 2,5; 5 та 12,5 мг/кг маси тіла протягом 45 діб відбувається вірогідне зростання концентрації середньомолекулярних ииркулюючих імунних комплексів у сироватиі крові птиці всіх дослідних груп порівняно з контрольною. Також у курей-несучок дослідних груп відзначена тенденція до зростання ступеня ендогенної інтоксикації, про щзо свідчить збільшення в сироватиі крові вмісту молекул середньої маси.
\end{abstract}

Ключові слова: кури-несучки, цииркулюючі імунні комплекси, аџетат свинцю, інтоксикація, імунобіологічні показники, молекули середньої маси.

Постановка проблеми. Багаточисленними дослідженнями встановлено, що в останні десятиліття вплив негативних техногенних факторів на довкілля став більш інтенсивним і масштабним $[2,6]$. Одним з основних негативних наслідків такого впливу є погіршення стану довкілля за рахунок надходження забруднюючих речовин в екосистеми та їх міграція по харчових ланцюгах [1]. Як відомо з літературних джерел, на даний час особливе місце серед хімічних полютантів займають сполуки важких металів, які є одними iз пріоритетних забруднювачів навколишнього середовища. Стійкість металів у об'єктах довкілля та включення їх до колообігу речовин (розчинність у атмосферних опадах, здатність до сорбції грунтами, донними відкладами, засвоєння рослинами) - все це в сукупності призводить до їхнього поступового накопичення у трофічних ланцюгах [3]. Серед них варто виокремити сполуки свинцю, який $є$ одним 3 найпоширеніших токсикантів 3 групи важких металів, що часто міститься у відходах промислового виробництва. Даний елемент не піддається деструкції і біотрансформації, а лише перерозподіляється між окремими компонентами екосистеми [9]. Щоправда, за даними ВОO3, гострі отруєння тварин і птиці сполуками важких металів у наш час трапляються досить рідко, тому особливої актуальності набуває проблема довготривалого впливу на організм малих доз ксенобіотиків [3].

Аналіз основних досліджень і публікацій, у яких започатковано розв'язання проблеми. У науковій літературі повідомляється, що важкі метали можуть пошкоджувати мембрани клітин, змінювати їх проникність, знижувати стійкість до осмотичного шоку, порушувати біоенергетичні процеси в клітинах [8]. Зокрема, сполуки свинцю здатні впливати на імунну систему, пригнічувати неспецифічну резистентність і стійкість організму тварин та птиці до інфекцій, стимулювати автоімунні реакції [11]. Встановлено, що надходження в організм даного ксенобіотика супроводжується інгібуванням синтезу окремих імунних білків та їх комплексів [2]. Однак, наявна у наукових повідомленнях інформація щодо впливу йонів свинцю на імунну систему птиці досить обмежена, а проаналізовані показники $є$ суперечливими $[12,13]$. Таким чином, з'являється необхідність дослідження змін імунобіологічних показників крові птиці за аліментарної хронічної інтоксикації ацетатом свинцю.

Мета і завдання досліджень. Метою нашої роботи було дослідження змін деяких імунобіологічних показників курей-несучок у відповідь на дію різних доз ацетату свинцю за хронічної інтоксикації.

Завданням роботи було дослідити зміни концентрації ЦІК і МСМ у сироватці крові курейнесучок за впливу на їх організм різних доз ацетату свинцю.

Матеріали і методи. Для вирішення поставлених завдань було сформовано чотири дослідні групи курей: контрольна і три дослідні за принципом аналогів, враховуючи масу тіла та фізіологічний стан. Кожна група складалася 3 п'яти курей-несучок кросу Lohmann Brown віком 210 діб та середньою живою масою по групі 1,81,9 кг на початок досліду. Утримання курей кліткове, з вільним доступом до корму і води. Птиця всіх груп отримувала стандартний комбікорм, збалансований згідно 3 нормами живлення (4169 Р, ТзОВ «ПРОВІМІ»). 


\section{СТОРІНКА МОЛОДОГО ВЧЕНОГО}

Токсичне ураження птиці важкими металами викликали шляхом щоденного внутрішньо шлункового введення водного розчину ацетату свинцю $\left(\mathrm{Pb}\left(\mathrm{CH}_{3} \mathrm{COO}\right)_{2}\right)$ протягом 45 діб в дозах (у перерахунку на катіон металу): I група 2,5 мг/кг, II група - 5 мг /кг, III група - 12,5 мг/кг маси тіла птиці.

Матеріалом досліджень була змішана периферична кров, яку отримували після забою птиці. У крові визначали рівень середньо-молекулярних циркулюючих імунних комплексів - у реакції преципітації з поліетиленгліколем (ПЕГ); вміст молекул середньої маси в сироватці крові визначали спектрофотометрично [10].

Експерименти проводили відповідно до конвенції Ради Свропи щодо захисту хребетних тварин, які використовуються для експериментальних і наукових цілей (Страсбург, 1985). Статистичну обробку одержаних цифрових даних проводили за допомогою комп'ютерної програми Excel (Microsoft, США). Вірогідність розходжень між показниками оцінювали за критерієм Стьюдента.

Результати досліджень. Аналіз отриманих даних вказує, що показники крові курей-несучок дослідних груп, які піддавалися свинцевій інтоксикації, суттєво відрізнялися від значень показників крові контрольної птиці.

Для 3'ясування фізіолого-біохімічних механізмів впливу іонів свинцю на стан імунної системи досліджено вміст середньомолекулярних імунних комплексів у сироватці крові піддослідних курей. Відомо, що за фізіологічних умов утворення та присутність циркулюючих імунних комплексів (ЦІК) у крові та лімфі $\epsilon$ одним із проявів імунної відповіді організму на надходження антигенів і важливим чинником, що забезпечує імунітет. ЦІК характеризують ступінь антитілоутворення в організмі тварин, спрямованого на елімінацію патогенних антигенів з організму [7]. Їх відносять до високомолекулярних білкових сполук, структура та функції яких залежать від фізико-хімічних й біологічних властивостей антигену й антитіла. Однак, розлади імунного гомеостазу призводять до тривалої циркуляції імунних комплексів у фізіологічних рідинах організму та сприяють нагромадженню їх у тканинах. Це, в свою чергу, зумовлює посилену агрегацію та адгезію тромбоцитів, що призводить до порушення мікроциркуляції крові й облітерації судин гемомікроциркуляторного русла, пошкодження i некрозу тканин [4].

Із даних, наведених у таблиці, видно, що збільшення дози токсиканта $(2,5 ; 5 ; 12,5$ мг $\mathrm{Pb}(\mathrm{II})$ на кг маси тіла) у раціоні веде до вірогідного зростання концентрації ЦІК у крові дослідних курей, що становило, відповідно, 60,6士1,86, $67,6 \pm 1,53$ і 74 $\pm 2,09$ проти контролю - 51,6 $\pm 2,44$ ммоль/мл. Таким чином, у першій дослідній групі, у якій птиці вводили 2,5 мг $\mathrm{Pb}(\mathrm{II}) /$ кг маси тіла, загальна концентрація середньомолекулярних ЦІК збільшилася на 17,4 \%, у другій, у якій птиця отримувала 5 мг $\mathrm{Pb}(\mathrm{II}) /$ кг маси тіла, - на $31,01 \%$, а в третій групі, де доза свинцю становила 12,5 мг $\mathrm{Pb}(\mathrm{II}) /$ кг маси тіла, - на 43,41 \% порівняно з контролем. Збільшення кількості ЦІК у крові курей під впливом йонів свинцю може бути обумовлено не тільки синтезом антитіл, а й порушенням механізмів їх елімінації.

Відомо, що довготривале надходження в організм токсиканта спричинює отруєння за рахунок підвищення його концентрації в крові та внаслідок розвитку ендогенної інтоксикації неспецифічного патологічного процесу, який із певного моменту протікає незалежно від етіологічного фактора й генералізується за накопичення в організмі токсичних продуктів порушеного метаболізму [5].

Основною причиною розвитку ендотоксикозу $\epsilon$ накопичення пулу сполук середніх молекул, що володіють різною біологічною активністю: порушують йонну проникність біомембран, інгібують ферментні системи та ін. Молекули середньої маси - це, в основному, фрагменти неповного протеолітичного розщеплення білків, які виявляються в біологічних рідинах організму в результаті недостатності функції системи природної біологічної детоксикації.

Зміни концентрації ЦІК та вмісту МСМ у сироватці крові курей-несучок за дії різних доз ацетату свинцю $(M \pm m, n=5)$

\begin{tabular}{|l|l|l|l|l|}
\hline \multirow{2}{*}{ Показник } & \multicolumn{4}{|c|}{ Група } \\
\cline { 2 - 5 } & \multicolumn{1}{|c|}{ контроль } & \multicolumn{1}{|c|}{ I дослідна } & \multicolumn{1}{c|}{ II дослідна } & III дослідна \\
\hline ЦІК, ммоль/мл & $51,6 \pm 2,441$ & $60,6 \pm 1,86^{*}$ & $67,6 \pm 1,536^{* * *}$ & $74 \pm 2,098^{* * * *}$ \\
\hline МСМ, у.о. & $0,179 \pm 6,648$ & $0,203 \pm 4,087^{*}$ & $0,217 \pm 5,573 * *$ & $0,228 \pm 4,707 * * *$ \\
\hline
\end{tabular}

Примітка: вірогідність відмінностей у порівнянні з відповідними показниками у контролі: * - p<0,05, $* *-\mathrm{p}<0,01, * * *-\mathrm{p}<0,001$ 


\section{СТОРІНКА МОЛОДОГО ВЧЕНОГО}

Аналіз результатів досліджень показав, що внаслідок хронічної інтоксикації ацетатом свинцю протягом 45 діб у крові курей усіх дослідних груп спостерігали вірогідне збільшення вмісту МСМ порівняно $з$ птицею контрольної групи: у першій дослідній групі на 13,4 \%, у другій і третій - на 21,2 \% і 27,3\% відповідно.

У цілому на основі отриманих даних можна зробити висновок про те, що катіони плюмбуму виявляють дозозалежний вплив на імунобіологічні показники курей-несучок.

\section{Висновки:}

1. Внаслідок хронічної інтоксикації курейнесучок ацетатом свинцю в дозах 2,5; 5 та 12,5 мг

\section{БІБЛІОГРАФІЯ}

1. Бокова Т. И. Эколого-технологические аспекты поведения тяжелых металлов в системе почва - растение - животное - продукт питания человека / Т. И. Бокова. - РАСХН. Сиб. отд-ние. - Новосибирск : ГНУ СибНИТИП, 2004. - 206 с.

2. Дмитруха Н. М. Експериментальне дослідження впливу ацетату свинцю, препаратів «Альгінат кальцію» та «Кверцетин» на імунологічну реактивність організму білих щурів / Н. М. Дмитруха, I. О. Голуб // Актуальные проблемы транспортной медицины. - 2005 , № 2. - С. 74-80.

3. Довгалюк A. Забруднення довкілля токсичними металами та його індикація за допомогою рослинних тестових систем / А. Довгалюк // Біологічні студії. - 2013. - Т. 7, №1. - С. 197-204.

4. Казмірчук B. Є. Клінічна імунологія і алергологія / В. С. Казмірчук, Л. В. Ковальчук. Вінниця : Нова книга, 2006. - С. 267-275.

5. Медицинская токсикология: национальное руководство / Под ред. Е. А. Лужникова. - М. : ГЭОТАР-Медиа, 2012. - 928 с.

6. Мельникова Н. М. Важкі метали як фактор екологічної небезпеки / Н. М. Мельникова, I. В. Калінін, Є. А. Деркач [та ін.]. - К. : НУБіП України, 2009. - 192 с.

7. Онисковец̧ь М.Я. Вплив свинцю на імунобіологічні показники Cyprinus carpio L. / М. Я. Онисковець, В. В. Снітинський // Біологія тварин. - 2011. - Т. 13, № 1/2. - С. 432-436.
$\mathrm{Pb}(\mathrm{II})$ на кг маси тіла встановлено зростання вмісту середньомолекулярних ЦІК у птиці всіх дослідних груп порівняно з контролем. Це вказує на наявність тісного зв'язку між проявом токсичної імуносупресії йонів свинцю зі зміною концентрації ЦІК у сироватці крові, що в цілому свідчить про суттєве зниження детоксикаційного потенціалу імунної системи дослідної птиці.

2. Встановлено зростання вмісту МСМ у сироватці крові курей-несучок дослідних груп, що вказує на розвиток ендотоксикозу та зміну гомеостазу організму в бік посилення катаболічних процесів.

8. Прокопенко В. В. Чувствительность молекулярных, надмолекулярных и клеточных биообьектов к катионам тяжелых металов / В. В. Прокопенко, Ю. Н. Набока, Л. А. Метелица // Соврем. проблемы токсикол. - 1999. - №3. C. $18-21$.

9. Трахтенберг I. М. Свинцева небезпека в Україні: сучасні реалії, проблеми та шляхи вирішення / I. М. Трахтенберг, С. П. Луговський, Н. М. Дмитруха [та ін.] // Науковий журнал МO3 України. - 2013. - № 3 (4). - С. 50-61.

10. Фізіолого-біохімічні методи досліджень у біології, тваринництві та ветеринарній медицині: довідник / [авт.-упоряд. В. Влізло та ін.]. - Львів : видавництво «ВМС», 2004. - 399 с.

11. Jung D. Immunotokxicity of co exposures to heavy metals: In vitro studies and results from occupational exposure to cadmium, cobalt and lead / D. Jung, U. Bolm Audorff, A. Faldum [et al.] // EXCLI Journal. - 2003. - №2. - P. 31-44.

12. Truscott $R$. B. Endotoxin studies in chicks: effect of lead acetate / R. B. Truscott // Can. J. Comp. Med. Can. J. Comp. Med., 1970. - Vol. 34. P. 134-137.

13 Vengris $V$. E. Lead Poisoning in Chickens and the effect of lead on interferon and antibody production / V. E. Vengris, C. J. Mare. // Can. J. Comp. Med., 1974. - Vol. 38. - P. 328-335. 